\title{
Literacy through literature
}

\author{
T.N. Mlandu* \\ Soweto College of Education, P.O. Box 90064, Bertsham, 2013 Republic of South Africa
}

\section{Bester}

Department of Information Studies, Rand Afrikaans University, P.O. Box 524, Auckland Park, 2006 Republic of South Africa mb@info.rau.ac.za

Received August 1997; accepted September 1997

\begin{abstract}
It is most important that a child's language and reading skills should be developed to its fullest potential. The aim of this article is to gain insight into the state of research and consensus in the literature on the value of children's literature for language acquisition, second language and literacy learning. Different ways in which a child can be brought into contact with books are also discussed. The impact of the research on South African educationalists and publishers are explored. Some local programmes and products to promote reading are discussed.
\end{abstract}

Dit is belangrik dat ' $n$ kind se taal- en leesvaardighede tot hul volle potensiaal ontwikkel word. Die doel van hierdie artikel is om insig te verkry in die stand van navorsing en heersende menings oor die waarde van kinderliteratuur vir die aanleer van taal, ' $n$ tweede taal en vir die verkryging van geletterdheid. Verskillende maniere waarop die kind in aanraking met literatuur gebring kan word, word bespreek. Daar word ook gekyk na leesreekse en programme wat in Suid-Afrika ontwikkel is om geletterdheid deur middel van lees te bevorder.

*Author to whom correspondence should be addressed.

Language gives a child the ability to communicate. Without appropriate language skills a child becomes progressively disadvantaged for, as the Bullock report (1975) comments, he may lack means to explain, inquire, hypothesize, analyse, compare and deduce. Basic literacy refers to the ability to read and write, but Cooper (1993:6) defines literacy as an activity that involves all of the language arts, namely, reading, writing, speaking and listening with thinking being part of each of these elements. Language is the critical intermediary between people, language impacts upon reading and writing, reading and understanding. Language also impacts upon thinking. It is therefore most important that a child's language skills should be developed to its fullest potential.

Research has shown that if children are exposed to stories they are also exposed to natural language that continually help them develop and expand their own language structures. Literature provides children with opportunities to experience many language structures and an ever-increasing vocabulary. The richness and the beauty of language is expressed in words, art and illustrations that expands the child's language experiences, schemata and forms the foundation for constructing meaning (Cooper 1993:18).

Cooper (1993) indicates that the use of literature as a basis for literacy and language learning will capitalize on what most children know when they come to school and will expand upon those existing structures. Literature gives children meaningful texts so that they can learn to read by reading, hence the saying we do not achieve literacy and give children literature, but we achieve literacy through literature (Cooper 1993:19).

According to Bester and Osborne (1991:171) children's literature consists of those books which by consensus of adults and children were assigned to the children's shelves.
They are those books that appear on the children's list of the publisher. Children's literature may also be defined as those books which are specifically written for children and intended to be read as literature and not only for information and guidance (Egoff 1981). Darton (1982:1) defines children's literature as works produced ostensibly to give children spontaneous pleasure, and not primarily to teach them, nor solely to make them good, nor to keep them profitably quiet. It is literature that should not be distanced from the main literature, but it should be seen as emanating from the main body of literature. Children's literature is written and published with the expectations that children will read it.

In the light of the above, it is the aim of this article to gain insight into the state of research and the consensus in the literature on the value of children's literature for language acquisition, second-language acquisition and literacy development.

\section{Language development}

The impact of a literature-based program on language achievement is an important issue. 'Children's literature is looked upon as an important source for instruction' (Morrow 1992:251). She indicates that children who are exposed to literature at a younger age tend to develop sophisticated language structures, vocabulary and syntax, which indicates that both language development and reading success can be improved by regular exposure to literature. Children gain knowledge, discover how language works and they also get to know how written language differs from spoken language. As the child listens to and later reads literature he gains more vocabulary, thus developing his language. 
MacDonald and Cornwall (1995) argues that for a child to be competent or fluent in a language he needs to learn new words, master them and be able to use them. They also indicate that in our highly verbal culture an accurate understanding of the meanings of words is a necessary pre-requisite for reading with meaning. Their research proves that vocabulary tests can serve as an effective measure of general intelligence, and most good intelligence tests contain many vocabulary items. An essential for intelligent reading is an understanding of the words used by the author. Vocabulary development is related to reading comprehension skills during high school (MacDonald \& Cornwall 1995:525).

Huck, Hepler and Hickman (1993) state that vocabulary seems to grow as children spend time with literature. Statistics indicate that children in third grade and above, learn the meanings of about 3000 new words each year and it is assumed by researchers that many of these new words are acquired by children in the context of their reading. They confirm that reading aloud to children, discussing literature with children and children's independent reading are all positive influences on literacy development.

'Studies showing that reading enhances literacy development lead to an uncontroversial conclusion, that reading is the only way children can become good readers, develop a good writing style, an adequate vocabulary, advanced grammar, and is the only way to become good spellers' (Krashen 1993:23).

$\mathrm{He}$ also indicates that reading aloud is not only good for vocabulary development in the pre-schools, but at secondary and tertiary level, children who are read to regularly for several months make superior gains in reading comprehension and vocabulary as well. Even short-term studies show significant increases in vocabulary knowledge after just a few hearings of stories containing unfamiliar words. Vocabulary development goes hand in hand with language development and this process starts before the child starts school. As the child acquires more vocabulary, he learns how to use it, and tends to develop more language skills. Cohen (1968) as quoted by Morrow (1992) confirms the above as he states that language development correlates with reading success and that both can be improved by regular exposure to children's literature.

The pre-literacy phase is an important period of language development. According to Huck, Hepler and Hickman (1993) the potential for the language development of children at 18 months is phenomenal, pre-occupation with words and the sounds of language is characteristic of very young children. Books will help to fulfill the desire to hear and learn new words. Parents are expected to start reading to children as early as possible, because it is believed that a young child who has the opportunity to hear and enjoy many stories is also beginning to learn to read. Through constant exposure to stories and books, children develop some early concepts about print. The pre-reading stage is often referred to as the emergent level of reading and is essential for later success in reading.

There are different ways in which a child can be brought into contact with language and a few of these possibilities will be discussed.

\section{Story telling}

Olën (1990:386) recommends storytelling by parents, child minders, librarians and teachers as one of the best techniques to expose children to literacy. From the earliest times to the modern age of television, people have found delight in hearing stories. Children at all levels should have the opportunity to hear good stories everyday.

\section{Using picture books}

For pre-scholars and elementary classes worldless picture books are recommended by many researchers for language acquisition. According to Lemmer (1989:21)

'wordless picture books aid children in developing many essential pre-reading and book processing skills like story construction through sequential thinking, predicting outcomes, inferential thinking, visual discrimination and page-turning'.

Huck, Hepler and Hickman (1993) agree that in wordless picture books, the pictorial prompts provided promote expressive language skills through strategies such as the creating of group dialogues and stories in oral and written form. Such approaches help children to experience the interrelated nature of speaking, listening, reading and writing in that particular language.

According to Lemmer (1989:21) picture books are normally neglected at upper levels of education because there is an assumption that picture books are for the innocent early years only, thereafter children are to be steered away from pictures into the more demanding world of print. This deprives children in the post-reception years of story motivation, a bridge to reading skills acquisition, exposure to challenging picture books, valuable stimulus material and contexts for language development tasks, opportunities for acquiring visual and screen literacy. Picture books contribute a lot in language acquisition because they provide the means of acquiring confidence in books and provide reading motivation.

Huck, Hepler and Hickman (1993:211) emphasize that picture books are particularly useful in stimulating language development through encouraging children to take an active part in storytelling. They also indicate that, as the child relates the story, he becomes aware of beginnings, endings, the sequence of the story, the climax and characters. All these are necessary for developing a sense of story. There are a number of ways to introduce children to picture books.

\section{Reading aloud}

Research has shown that children who have been read to learn to read better and with fewer problems when they go to school. According to Olën (1990:382) the activity of reading 
aloud stimulates children's interest, emotional development, imagination, develops the childrens vocabulary and makes them to be more sensitive to language. At the same time it prepares children for formal education.

Reading aloud to young children according to Hough, Nurss and Enright (1986:510) has been advocated as a natural device for promoting oral language development and initiating monolingual children into literacy. Cochran-Smith (1983), Holdaway (1979) and Teal (1982) in Hough, Nurss and Enright (1986:511) agree with each other that early adultchild interactions with books help children develop concepts, oral fluency and a sense of story. Frequent reading of stories to pupils helps them to acquire that particular language, to figure out grammar and to make predictions. Reading aloud and talking about books give pupils an opportunity to apply their common language learning strategies.

\section{Book reading}

Book reading brings children into touch with story structures and schemes as well as literacy conventions which are prerequisites for understanding texts. Mason and Allen (1986) in Bus, Van Ijzendoorn and Pellegrini (1995:2) say that reading books to children exposes them to the written language register. Grammatical rules for spoken and written language may be the same, but the use of the options that grammar offers, turns out to be quite different in speaking than in writing. Children learn how to use and understand the written language register prior to learning the mechanical skills of encoding and decoding print. Younger and less experienced children recite books with a wording and an intonation appropriate for oral situations, whilst older and more experienced children use language that was worded increasingly like written language and like the text of the book itself.

\section{Book sharing}

Book sharing is a method whereby pupils could acquire language skills through reading. Bus, Van Ijzendoorn and Pellegrini (1995) have studied the way in which parents share books with young children and they concluded that one of the first language patterns or frames that a parent and child develop is in relation to sharing a picture book. Parents use a consistent language pattern when labeling objects in a picture. The parents point at the picture and names it, then the child imitates. Both participants' attention will be jointly focussed on the pictures and words that stay the same for each reading, therefore the child can predict the story and build up a vocabulary over numerous readings. At school, Lemmer (1989), Elley and Mangubhai (1983) have shown shared reading to be successful 'in the elementary classes. Elley and Mangubhai (1983:56) emphasize the point that if children enjoy the experience they will want to read often, in class groups, in small groups, in pairs or as individuals. They will therefore be able to master the written language in the book with the minimum of pressure and strain, because new learning of the language takes place at the point of interest.

\section{Using comic books}

Comic books are valuable material for language development in upper classes. Research done on comic book texts and on the impact of comic book reading on language development and school performance suggests that comic books are not harmful and there is considerable evidence that comic books can and do lead to more serious reading (Krashen 1993:50).

Krashen (1993) has also established that those who continue to read comics after the early grades, are at least equal to non-comic readers in reading, language development and overall school achievement. An exclusive diet of comic books will probably develop adequate but not advanced levels of competence in language and literacy development. There is also evidence that light reading can serve as a conduit to heavier reading. It can help readers not only develop the linguistic competence for more advanced reading but can also develop an interest in books. Many case studies show that comic book reading can lead to additional book reading. The results of case studies by Lemmer (1989) and Krashen (1993) support the view that reading comics is the way many, if not most children learn to read, and get a taste of reading. Even reluctant readers feel motivated by comics. Comics bring appeal where all other printed matter has failed. Indeed comics motivate children to read more. The texts of comics are actually linguistically appropriate, and pictures can help make the texts more comprehensible.

In conclusion, it could be said that reading enhances vocabulary and language development from pre-literacy to the upper levels of education. Wordless books, picture books and story books are more effective in pre-school, whilst novels and comics are recommended for older children. Children who have acquired language through reading, do not experience communication problems in that particular language, they become literates through the use of literature.

\section{Second-language acquisition}

A child first learns to speak his mother tongue, then when he starts school in South Africa, a second language is introduced. Ellis (1985:6) describes second-language acquisitions as

'the subconscious or conscious processes by which a language other than the mother tongue is learnt in a natural or a tutored setting. It covers the development of phonology, lexis, grammar and pragmatic knowledge'.

Elley and Mangubhai (1983) in their investigation into second-language acquisition have noticed that second language is learnt so laboriously and ineffectively in the classroom, yet so readily when the learner is part of a community that speaks the language. Recent case studies of secondlanguage learners suggest that second-language acquisition in naturalistic contexts has much in common with first-language 
acquisition, and repeated exposure to high interest illustrated story books in the target language is recommended to produce rapid second-language acquisition.

According to Elley and Mangubhai (1983:54) secondlanguage learning can be effective if strategies derived from understanding of first-language learning are used. These strategies include the total immersion in second language from school entry, partial immersion and prolonged passive exposure before oral expression. Olën and Machet (1997:85) states that 'just as spelling and vocabulary are developed in first languages by reading, so too they are developed in second languages'. Hough, Nurss and Enright (1986:510) exclaim that

'the challenge today for all teachers of linguistic minority pupils is to capitalize on children's diverse linguistic and cultural experiences to introduce them to their new language and culture and to provide them with full access to the education system'.

To meet this challenge, activities and instructional techniques are needed, and one of those which is highly recommended by most researchers is:

\section{Story reading}

All children find story reading with adults pleasurable. Elley and Mangubhai (1983) and Hough, Nurss and Enright (1986) state that it is an important second-language acquisition tool, because it increases the efficiency of second-language learning which could be attempted profitably through the use of an abundance of high interest, illustrated story books printed in the target language. When children read such story books they are engaging themselves in an activity which reduces the effect of first- and second-language differences. The reading of story books play a dominant role in determining what language children learn, when they learn it, and how they learn it. 'High interest story books provide a basis for language learning which goes a long way to bridge the gap between first and second learning contexts' (Elley \& Mangubhai 1983:56). Good story books provide strong intrinsic motivation for children and an emphasis on meaning rather than form.

When children are read to, they get an opportunity of hearing a variety of fiction and non-fiction books, and they go through a silent period of second-language acquisition (Mlandu 1997:29). During this period their primary task is to develop their receptive second-language skills in preparation for expressing themselves later. Lemmer (1989) and Elley and Mangubhai (1983) also support the statement that storyreading facilitates second-language acquisition because children participate by watching and listening to the teachers and other children as they ask and answer questions or comment on the story. Questions asked by the pupils, allow the pupils to build meaning and to acquire the language. They can also use the same questions asked to them in their own situations.

The following strategies in story reading help monolingual children develop second-language skills.

\section{Using picture books}

According to Elley and Mangubhai (1983) to increase the efficiency of second-language learning an abundance of highinterest picture books printed in the target language can be used. When children read such picture books they are engaging themselves in an activity which reduces the effect of first- and second-language differences. Picture books assist children to learn naturally, form context and provide excellent models of the written language. The books provide a means of acquiring confidence in the second language, a familiarity with books together with reading motivation via fruitful entertainment. Well illustrated books provide additional context for children to use during story reading.

Picture books provide a useful bridge to reading skills, for instance, narrative grammars of picture books often contain repetitive structures and opportunities for participation. They attempt to maintain constant focus on constructing the meaning throughout the process and are always seeking the most direct path to meaning. According to Lemmer (1989:23) through picture stories, pupils can be exposed to quality language that are both accessible and challenging. Lemmer (1989) agrees with Hough, Nurss and Enright (1986) that, there is a number of picture books where the stories told by text and paintings contain resonances and dimensions that can open up psychological, social, moral, political and literary questions and awareness.

\section{Free voluntary reading}

Free voluntary reading according to Krashen (1993:10) refers to 'reading because you want to'. He regards it as one of the most powerful tools available in language education and the most effective way of achieving proficiency in a second language. Olën and Machet (1997:85) indicate that in South African schools, the teaching of reading has largely focussed on skills, strategies and the process individual readers acquire and use as they interact with a piece of text. They also indicate that free voluntary reading is the most important determinant of vocabulary development, writing competence and the ability to comprehend and utilize advanced grammatical structures.

\section{Extensive reading}

Older children should be encouraged to read extensively. Research has proved that pupils gain more information when they read on their own, at their own pace, and decipher words on their own, and this could be achieved through extensive reading.

Extensive reading is an activity that provides a learning environment within which learners have access to large quantities of written material in the second language for personal interest reading. According to Davis (1995:329)

'an extensive reading program is a supplementary class library scheme attached to a specific language course, in which pupils are given the time, encouragement and materials to read pleasurably at 
their own level, as many books as they can without the pressures of testing or marks'.

Extensive reading practised for second-language acquisition would differ from the more frequently practised free voluntary reading. The difference being in the amount of second-language material, as well as the intensity with which the material is studied. In intensive reading activities learners are in the main exposed to relatively short texts which are used either to exemplify specific aspects of the lexical, syntactic or discoursed system of the second language or to provide the basis for targeted reading strategy practise. On the other hand extensive reading exposes learners to large quantities of meaningful and interesting language material, which in the long run produce a beneficial effect on the learner's command of the second language. Nuttall (1982) in Hafiz and Tudor (1989:5) claims that extensive reading is the best way of acquiring proficiency in a language whilst Wilkins (1972) in Hafiz and Tudor (1989:5) maintains that,

'through reading, the learner is exposed to the lexical items embedded in natural linguistic contexts and as a result they begin slowly to have the same meaning-

fulness to him that they have for the native speaker'.

Pupils tend to enjoy an extensive reading program because in this type of activity they are competing against themselves, a teacher is a monitor or he motivates them just to ensure that the maximum number of books are being read in the time available. The catchwords are quantity and variety, rather than quality (Mlandu 1997:33). Non-fiction and teenage magazines are included but fiction predominates. According to Davies (1995:335) any second-language classroom will be the poorer for the lack of an extensive reading program of some kind, and will be unable to promote its pupils' secondlanguage development in all aspects as effectively as if such a program was present. This is true of every level whether primary, secondary or tertiary, but is particular true at lower secondary where there is time for extra reading, without the pressure of public examinations.

In conclusion it could be stated that reading literature helps readers to acquire all the concepts necessary to understand or comprehend the language that is not their own. South Africa is a multi-lingual country, we have eleven official languages. All children will have to acquire a second or even a third language besides their mother tongue. The implications are that South African children should at all costs be motivated to become readers.

\section{Reading motivation}

Since the benefits of reading have been proved conclusively, the next step would be to ensure that all children read as much as possible. Underlying this effort is the problem of motivating children to read.

Motivating children to read should be one of the primary and overriding concerns in present-day education in South Africa. Research shows that there is a link between motivation and achievement. Gambrell (1996) and Koskinen (1994) agree that highly motivated readers are self-determining and generate their own reading opportunities. They want to read and choose to read for a wide range of personal reasons like curiosity, involvement, social interchange and emotional satisfaction. By so doing, they begin to determine their own destiny as literacy learners. Research supports the notion that literacy learning is influenced by a variety of motivational influences. Pupils who believe they are capable and competent readers are more likely to outperform those who do not hold such beliefs and students who perceive reading as valuable and important and who have personal reasons for reading will engage in reading in a more planned and effortful manner. They become engaged readers. Gambrell (1996) describes an engaged reader as motivated, one who chooses to read for a variety of purposes like gaining new knowledge, escaping into the literary world of the text and learning how to perform tasks. An engaged reader is knowledgeable because he is able to use information gained from previous experiences to construct new understanding from text, to acquire knowledge from text, to apply knowledge gained from text reading in a variety of personal, intellectual and social contexts. He is strategic in the sense that he is able to employ cognitive strategies to decode, interpret, comprehend, monitor and regulate the reading process to satisfy goals and purposes of reading. Lastly an engaged reader is socially interactive, able to share and communicate with others in the process of constructing the meaning of text. This is the kind of reader educators must aim at when motivating.

\section{Fostering reading motivation}

Teachers play a critical role in helping children develop into readers who read for both pleasure and information, therefore they should create classroom cultures that support and nurture children in becoming highly motivated readers. This can be accomplished by

\section{Reading models}

Teachers, librarians and parents are motivating influences. They should be explicit reading models. Explicit reading models occur when teachers share their own reading experiences with students and emphasize how reading enhances and enriches their lives.

\section{Book-rich environment}

Classroom libraries and personal libraries at home appear to be important influences on motivation to read. Various studies provide support for the notion that when children have environments that are book-rich, the motivation to read is high. Opportunities for book borrowing and avenues for obtaining books for home reading are significant factors in reading motivation. Greater attention should be devoted to assuring that high quality classroom libraries are a priority in schools (Koskinen 1994:177). 


\section{Opportunities for choice}

Book choice is a very important factor in reading motivation, and its role in motivation in general is well recognized. Opportunities for choice promotes students independence and versatility as readers.

\section{Social interactions}

Children often choose books because someone had told them about it, it could be a friend or parents. Book sharing, book clubs, discussion groups, teacher read-aloud sessions are all motivating factors. The more books that children are exposed to, and know about, the more books they are likely to read. Social interactions with others encourage motivation, promote achievement, higher level cognition and intrinsic desire to read.

In conclusion it can be said that teachers can make a real difference in the literacy lives of young children when they serve as reading models and motivates and create classroom cultures that are book-rich, provide opportunities for choice, encourage social interactions about books, build on the familiar books and reflect the view that books are the best rewards. By so doing they can change pupils' attitudes towards reading, even those who do not want to read will hopefully gain an interest in reading. Once interest is gained, they become voluntary readers, and as they read on their own they acquire vocabulary which lead to the development of their first and second languages.

\section{South African scenario}

The aim of the study was to gain insight into the state of research and consensus in the literature on language acquisition and reading motivation as gateways to literacy. It was confirmed that exposure to books enhances life-long learning. One can now rightly ask whether these concepts and opinions have also made their impact on South African educationalists.

In a first world context no-one would disagree with Huck, Hepler and Hickman (1993) that there is an important preliteracy phase where children should listen to stories and develop the desire to hear and learn new words and phrases. This is the phase when parents or care givers are expected to start telling or reading stories to children. Unfortunately the reality is that in South Africa caregivers in general were not supporting children's acquisition of literacy. According to Kriegler et al. (1993:72) even more distressing was the fact that they were also neglecting to teach youngsters the rich African cultural heritage of oral stories and songs. What has also been pointed out by most researchers is that adult education plays a most prominent role in promoting literacy and the implication is that a child growing up in a literate family environment where reading, writing and the sharing of stories occur as part of the normal daily routine is at a distinct advantage when he starts school as compared to those pupils without reading preparation at home. The latter will be lacking preliteracy skills. In South Africa there is vast illiteracy with more than five million illiterate adults (Kruger
1990; Olën \& Machet 1997; Tötemeyer 1994). These illiterate adults have children who go to school, children whose ability to benefit from formal education is severely hampered by their home backgrounds, because they do not get proper support for learning. The learning implication is that South African children will enter primary school lacking preliteracy skills because they come from disadvantaged homes with no reading tradition. In a thought provoking article, Kriegler et al. (1993) discuss the situation in print bereft rural communities. They say that South African history has become a race between education and catastrophe. The research carried out in rural Venda focussed on rural school-beginners' preliteracy experience. The latter was found to be distressingly inadequate (Kriegler et al. 1993:72).

The research also assessed the adequacy and appropriateness of formal literacy instruction in five rural Venda schools. They found that reading lessons were conducted without pupils being given the opportunity to read or handle books! There were seldom, if ever, the opportunity to read continuous text. There were no books whatsoever in the classrooms.

Children need to be introduced to literacy in their mother tongue and the stories read should be contextually, linguistically and culturally appropriate (Kriegler et al. 1993). This entails picture books published in the mother tongue. South Africa has 11 official languages. There is a great demand for books in indiginous languages. To support this statement the public library service of the Western Cape reports that the biggest increase in demand was for Xhosa children's books but that children sometimes have to wait for up to a year for a book they ordered.

The importance of picture books for language development was discussed. In South Africa publishers are producing beautifully illustrated picture books relevant to South African children. The most notable example being the Little library project, winner of the IBBY-Asahi Reading Promotion Award.

A number of similar projects that have been undertaken as reading schemes published abroad just do not have a local relevance. Early reading series as the books created by READ, Kagiso's Zebra books, Hodder and Stoughton's Foundation books, Maskew Miller Longman's Sunny day readers and Shuter \& Shooter's Wordwise are much needed. Publishers such as Garamond, Anansi, Human \& Rousseau and Ithemba are producing quality picture books in African languages. SACBIB 95 lists 125 children's titles available in Xhosa and 80 in Zulu (Heale 1996:8).

Studies by READ proved beyond doubt the influence of flooding classrooms with books and then preparing the teachers in the ways of booksharing. Independent tests that READ has conducted in seven different provinces have compared schools running teaching programmes where pupils are actively encouraged in the voluntary reading of real books, to schools not using this approach. At a standard-five level, pupils in the first group of schools were approximately 18 months ahead of the others in terms of reading skills and two 
years ahead in terms of writing skills! (Mkhatshawa 1997: 37).

The impact of comic book reading on language development and as a reading incentive was also discussed. Comics can act both as a bridge to full reading (especially in English as second-language context) and as a valuable complementary activity. The acceptance of this fact lead to an interesting South African project.

In 1990 The Storyteller Group serialized a comic strip called 99 Sharp Street. It was a runaway success. Since 1990 was the International Year of Literacy, the group developed a 24-page colour comic strip story The river of our dreams. It was supported by an in-depth study on the use of such material in a classroom situation (Heale 1995:8). South African teachers see the use of such material as a bridge to full reading, especially in English as a second-language context. In 1994 Heart to heart was published by The Storyteller Group. The story was developed with the help of pupils from Gazankulu.

The reaction to The Storytellers Group's The river of our dreams proves that if books are accessible and acceptable they will be read. One teacher of a standard 7 class 'feared lynching if I tried to stop them reading it' (Heale 1993:8).

Children should be able to read and more importantly want to read. Literacy cannot be acquired unless it is experienced. Children must have extensive opportunities to read, and these opportunities must be created by adults.

One of the most successful reading motivation programmes in South Africa is the Readathon, organized annually by the Read Educational Trust (READ). It is a festival of books at the primary-school level and a public speaking and debating festival at the high-school level. More and more rural schools are participating in these events. This has led in some areas of parents taking the initiative to intercede with the authorities for books for the schools as a result of seeing what can happen when pupils begin to read. When parents truly understand their role and their rights in their children's education, major changes will result (READ 1995).

Because READ realizes that the best way to motivate readers is through integrated instruction they have started a number of projects to educate teachers to use books in teaching. There is, for example, the College of Education Project. Since most student teachers come from the same underresourced school backgrounds as their pupils, the student teachers, in many cases, have not had sufficient opportunity to practise their reading and language skills. These students learn about READ's methods and materials: READ believes that literacy can best develop when learners are motivated to read widely and to relate their reading to the world. READ believes that the only means to this end is the provision of carefully selected books. The books must be introduced together with teacher training to enable them to utilize the material. These teachers will then be able to motivate their pupils to read widely. They will be able to introduce motivational programmes as discussed (READ 1995).

\section{Conclusion}

All reading activities depend on the availability of a variety of appropriate books for children. It is most important that children have access to books. How is this possible if many parents can barely afford to pay school fees or even to feed their children?

Children must have access to libraries: school libraries, and/or public libraries. Slashed state funding has made it virtually impossible to imagine that each South African school could have its own library. Bristow (1992) looked at the role of the library in a developing community and suggested that in view of limited resources, a strategy for the underdeveloped areas of South Africa might be to establish the combination of a community (public) and school library. The national Department of Education established a Research Working Group to investigate a national policy framework for school library standards. A variety of school library models have been proposed to address the situation (South Africa 1997). As for public libraries, they face the daunting task to help schools to provide books to all South Africa's children, because all research confirms that the most powerful tool available for developing a child's language and increasing the ability to read and comprehend is reading.

\section{References}

Bester, M. \& Osborne, M.E. 1991. Critical approaches to children's literature. South African journal of library and information science, 59(3):171-181.

Bristow, A.P. 1992. The role of the rural school library in development. Mousaion, Series 3, 10(3):71-82.

Bullock, A. 1975. A language for life. London: HMSO.

Bus, A.G., Van Ijzendoorn, M.H. \& Pellegrini, A.D. 1995. Joint book reading makes for success in learning to read: a metaanalysis on intergenerational transmission of literacy. Review of educational research, 65(1):1-21.

Cooper, J.D. 1993. Literacy: helping children construct meaning. Boston: Houghton Mifflin.

Darton, F.J.H. 1982. Children's books in England: five centuries of social life. 3rd ed. London: Cambridge University Press.

Davis, C. 1995. Extensive reading: an expensive extravagance? ELT journal, 49(4):329-334.

Egoff, S.A. 1981. Trends and patterns in contemporary children's literature. Chicago: American Library Association.

Elley, W.B. \& Mangubhai, F. 1983. The impact of reading on second language learning. Reading research quarterly, 14(1):53-67; 329-334.

Ellis, R. 1985. Understanding second language acquisition. Oxford: Oxford University Press.

Gambrell, L.B. 1996. Creating classroom cultures that foster reading motivation. The reading teacher, 50(1):14-25.

Hafiz, F.M. \& Tudor, I. 1989. Extensive reading and the development of language skills. ELT journal, 43(1):4-11.

Heale, J. 1993. Home-grown literature. Bookchat, 111:8.

Heale, J. 1995. So called comics and their uses in combating illiteracy. Bookchat, 122:8.

Heale, J. 1996. The English language. Bookchat, 126:8. 
Hough, R.A., Nurss, J.R. \& Enright, D.S. 1986. Story reading with limited English speaking children in the regular classroom. The reading teacher, 39(6):510-513.

Huck, S.C., Hepler, S. \& Hickman, J. 1993. Children's literature in the elementary school. 5th ed. New York: Holt.

Koskinen, S. 1994. In their own words: what elementary students have to say about motivation to read. The reading teacher, 48(2): 176-178.

Krashen, S. 1993. The power of reading; insights from the research. Englewood: Libraries Unlimited.

Kriegler, S. et al. 1993. Supporting emergent literacy in print bereft rural communities. Pedagogiek joernaal, 14(2):69-89.

Kruger, E. 1990. The Gordian knot of South African education. Optima, 37(3):134-138.

Lemmer, A. 1989. Picture book stories as vehicles for language development. Journal for language teaching, 23(3):20-31.

MacDonald, G.W. \& Cornwall, A. 1995. The relationship between phonological awareness and reading and spelling achievement eleven years later. Journal of learning disability, 28(8):524-527.

Machet, M.P. \& Olën. S.I.I. 1997. Literacy environment of pupils in urban primary schools. South African journal of library and information science, 65(2):77-84.
Mkhatshawa, F.R.S. 1997. Stop the rot! Cape librarian, Sept./ Oct::36-37.

Mlandu, T.N. 1997. Literacy through literature. M.Inf. mini diss. Johannesburg: Rand Afrikaans University.

Morrow, M. 1992. The impact of a literature-based program on literacy achievement, use of literature and attitudes of children from minority backgrounds. Reading research quarterly, 27(3):255-274.

Olën, S.I.I. \& Machet, M.P. 1997. Research project to determine the effect of free voluntary reading on comprehension. South African journal of library and information science, 65(2):85-92.

Olën, S.I.I. 1990. Promoting reading aloud to the parents and other child-minders of pre-school children. South African journal of library and information science, 58(4):382-387.

Read Educational Trust. 1995. Annual review. Johannesburg: The Trust.

South Africa. Department of Education. 1997. A national policy framework for school library standards. Pretoria.

Tötemeyer, A. 1994. Speaking from a book; the transfer of derecorded information to the information starved. IFLA journal, 20(4):410-418. 